\title{
Review of the flood risk management system in Germany after the major flood in 2013
}

\author{
Annegret H. Thieken ${ }^{1}$, Sarah Kienzler $^{1}$, Heidi Kreibich $^{2}$, Christian Kuhlicke $^{3}$, Michael Kunz $^{4,5}$, Bernhard Mühr $^{4,5}$, Meike Müller $^{6}$, \\ Antje Otto $^{1}$, Theresia Petrow ${ }^{1,2,7}$, Sebastian Pisi ${ }^{7}$ and Kai Schröter ${ }^{2,5}$
}

\begin{abstract}
Widespread flooding in June 2013 caused damage costs of $€ 6$ to 8 billion in Germany, and awoke many memories of the floods in August 2002, which resulted in total damage of $€ 11.6$ billion and hence was the most expensive natural hazard event in Germany up to now. The event of 2002 does, however, also mark a reorientation toward an integrated flood risk management system in Germany. Therefore, the flood of 2013 offered the opportunity to review how the measures that politics, administration, and civil society have implemented since 2002 helped to cope with the flood and what still needs to be done to achieve effective and more integrated flood risk management. The review highlights considerable improvements on many levels, in particular (1) an increased consideration of flood hazards in spatial planning and urban development, (2) comprehensive property-level mitigation and preparedness measures, (3) more effective flood warnings and improved coordination of disaster response, and (4) a more targeted maintenance of flood defense systems. In 2013, this led to more effective flood management and to a reduction of damage. Nevertheless, important aspects remain unclear and need to be clarified. This particularly holds for balanced and coordinated strategies for reducing and overcoming the impacts of flooding in large catchments, cross-border and interdisciplinary cooperation, the role of the general public in the different phases of flood risk management, as well as a transparent risk transfer system. Recurring flood events reveal that flood risk management is a continuous task. Hence, risk drivers, such as climate change, land-use changes, economic developments, or demographic change and the resultant risks must be investigated at regular intervals, and risk reduction strategies and processes must be reassessed as well as adapted and implemented in a dialogue with all stakeholders.
\end{abstract}

Key Words: August 2002 flood; Central Europe; Floods Directive; governance; June 2013 flood; risk management cycle

\section{INTRODUCTION}

In June 2013, widespread flooding occurred in many Central European countries, i.e., in Switzerland, Austria, the Czech Republic, Slovakia, Poland, Hungary, Croatia, Serbia, and particularly in Germany, where, in hydrological terms, this flood can be regarded as the most severe event over at least the last 60 years (Merz et al. 2014). The event awoke many memories of flooding in August 2002, when record breaking rainfall amounts resulted in extreme discharges and water levels in the rivers Elbe and Danube and some of their tributaries (see Ulbrich et al. 2003, Engel 2004). Back then, the high hydraulic impact led to the activation of dam spillways as well as to overtopping and breaching of embankments in many places. Among other aspects, missing or incomplete flood warnings, bad maintenance of flood protection structures, as well as a lack of risk awareness and knowledge about adequate response were identified as weaknesses of the flood risk management (DKKV 2003, Thieken et al. 2005a). In Germany, 21 people were killed and the total damage amounted to $€ 11.6$ billion (reference year 2005 , Thieken et al. 2006). This amount exceeded losses of former disastrous events by far and has not been surpassed by the 2013 flood for which overall direct losses of $€ 6$ to 8 billion are assumed (Thieken et al. 2016).

After the floods in 1993 and 1995 along the Rhine River, a more integrated flood risk management had already been proposed by the German Working Group on Water Issues of the Federal States and the Federal Government (LAWA). However, these guidelines
(LAWA 1995) were not sufficiently reflected in the German water legislation. After the flood in 2002, many activities were launched on administrative and legislative levels (e.g., DKKV 2003, Heintz et al. 2012, Bubeck et al. 2015). Particularly, the German Flood Protection Act of 2005 (Artikelgesetz zur Verbesserung des vorbeugenden Hochwasserschutzes) and the European Floods Directive (2007/60/EC; EC 2007) introduced important changes in the German Federal Water Act (Wasserhaushaltsgesetz). This marked a further shift from a purely technically oriented flood defense toward a more integrated flood risk management system that also considers nonstructural measures to minimize adverse effects of flooding (Hartmann and Albrecht 2014).

Smaller flood events in 2005, 2006, 2010, and 2011 already revealed that regional and local governments as well as floodprone residents and companies had adapted to the flood risk and had implemented precautionary and preparatory measures (Kreibich et al. 2011a, Kienzler et al. 2015a). Because such highfrequency-low-impact-events are usually easier to cope with than extreme floods, the severe and widespread summer flood in 2013 offered the opportunity to evaluate how effective the measures were that politics, administration, and civil society had implemented since 2002. Therefore, the main research questions of this paper are the following:

- What changes have been made in the German flood risk management system since the flood of August 2002?

\footnotetext{
${ }^{1}$ University of Potsdam, Institute of Earth and Environmental Science, Potsdam, Germany, ${ }^{2}$ Helmholtz Centre Potsdam - GFZ German Research Centre for Geosciences, Section 5.4 Hydrology, Potsdam, Germany, ${ }^{3}$ Helmholtz Centre for Environmental Research - UFZ, Urban and Environmental Sociology, Leipzig, Germany, ${ }^{4}$ Institute of Meteorology and Climate Research, Karlsruhe Institute of Technology, Karlsruhe, Germany, ${ }^{5}$ CEDIM - Center for Disaster Management and Risk Reduction Technology, Karlsruhe, Germany, ${ }^{6}$ Deutsche Rückversicherung AG, NatCat-Center, Düsseldorf, Germany, ${ }^{7}$ German Committee for Disaster Reduction (DKKV), Bonn, Germany
} 
- Did these changes help to avoid and mitigate damage due to flooding in June 2013?

- What should be further done to achieve a more integrated flood risk management system in Germany?

To tackle these questions a review of the flood risk management system in Germany was undertaken from October 2013 to February 2015 and fully published by DKKV (2015). In this paper, the main findings are summarized.

\section{METHODOLOGICAL APPROACH}

For an analysis of how a society reacts and adapts to damaging events, the risk management cycle offers a valuable framework (e.g., DKKV 2003, Kienholz et al. 2004). In our review, three phases were considered:

- (emergency) response: during the event, immediate measures are undertaken with the priority to limit adverse effects and the duration of the event;

- recovery: after the event, the affected society starts to repair damage and to regain the same or a similar standard of living as before the damaging event happened;

- risk reduction: in this period, measures are planned and implemented that aim at minimizing risks.

Three main risk reduction strategies were distinguished: (1) flood control to avoid inundation of (urban) areas, (2) loss prevention by adapted use of flood-prone areas, and (3) preparedness for response and recovery. For the evaluation, each strategy was further divided into particular measures, which were reviewed in detail. Owing to the large spectrum of topics, a variety of approaches and methods was needed to collect and analyze appropriate data and information. For example, flood-related parliamentarian inquiries, policy documents and laws, publicly accessible flood hazard and risk maps, event documentations, and (media) reports were systematically searched to capture developments in flood risk management, particularly on the level of all 16 federal states in Germany (Länder) which are mainly in charge of flood risk management. This material was accompanied by written surveys among property insurers in Germany as well as among the supreme water authorities of all 16 federal states. The latter was followed by a stakeholder workshop in June 2014 to derive recommendations. Emergency response was evaluated on the basis of (internal) reports of relief and aid organizations on the flood of 2013. In addition, representatives of different relief and aid organizations were interviewed using a semistructured format and common recommendations were discussed at a workshop in November 2014 (DKKV 2015). Furthermore, the role of flood-prone residents as well as businesses was investigated by computeraided telephone interviews (CATI) of 1652 private households and 557 companies. Both questionnaires were comparable to surveys conducted after the flood in 2002 (see Thieken et al. $2005 b$ for the household survey and Kreibich et al. 2007 for the business survey). Finally, hydraulic and damage simulations were undertaken in two case studies to explore the interaction between public and private mitigation measures (see Kienzler et al. 2015b).

\section{THE FLOOD OF JUNE 2013 IN COMPARISON WITH AUGUST 2002}

\section{Meteorological conditions}

In Central Europe, abundant and widespread flood-producing rainfall is usually coupled to certain large-scale weather patterns (Bárdossy and Filiz 2005, Petrow et al. 2009) that also occurred in 2002 and 2013. In most cases an upper level trough, which is an elongated area of relatively low atmospheric pressure at about $5500 \mathrm{~m}$ asl, extends with its axis roughly from Denmark southward across Germany toward the central Mediterranean Sea. The northerly to northeasterly flow at lower levels of the troposphere causes the largest amounts of precipitation along the windward slopes of the west-east-oriented mountain ranges in Central Europe, e.g., the Ore Mountains (Erzgebirge) or the Alps.

In 2002, the largest rainfall amounts were observed in eastern Germany and exceeded $100 \mathrm{~mm}$ within 72 hours at many places, such as in large parts of Brandenburg and in most of Saxony. In the latter, a record breaking total of $312 \mathrm{~mm}$ within 24 hours was observed at the Zinnwald-Georgenfeld rain gauge in the Ore Mountains (Ulbrich et al. 2003). Similar amounts were also recorded in the Bavarian and Bohemian forests as well as in the foothills of the Alps (Fig. 1, bottom left panel).

In June 2013, an isolated upper-level low pressure system centered over Central Europe triggered the development of several surface low pressure systems that circled around the upper level low on similar tracks. This configuration resulted in a steady and significant transport of moist and warm air masses toward Central Europe. The Mediterranean Sea and the Black Sea served as sources of moisture, but evaporation from continental landmasses of southeastern Europe also played an important role (Grams et al. 2014).

The most intense rainfall occurred in the Danube catchment in the alpine areas of southern Bavaria and northern Austria. The German Weather Service's rain gauge of Aschau-Stein in the Chiemgau Alps reported a rainfall total of $346 \mathrm{~mm}$ within 72 hours (Schröter et al. 2015). Rainfall totals in excess of $100 \mathrm{~mm}$ also occurred in the Ore Mountains, along the Swabian Alb and in the northern Black Forest (Schröter et al. 2015; Fig. 1, bottom right panel). However, over a 24-hour period, Aschau-Stein received $170.5 \mathrm{~mm}$, which is far below the rainfall recorded in 2002.

\section{Hydrological processes and hydraulic impacts}

The floods in August 2002 and June 2013 were extreme events with regard to magnitude and spatial extent. A distinctive feature of the August 2002 flood was the extremely intense precipitation in the Ore Mountains (see above; Fig. 1 bottom left panel), which resulted in flash floods, e.g., on the rivers Mulde, Weißeritz, and Schwarze Elster. Discharge return periods were estimated to be 150-200 years at the Dresden gauge, 200-300 years at the Mulde River, and 100-300 years at the Regen River (Ulbrich et al. 2003, IKSE 2004; Fig 1, bottom left panel). In comparison, the flood in June 2013 was mainly driven by the combination of high catchment wetness due to a strong rainfall anomaly during the month of May (Fig. 1, top right panel) and spatially extended high but not extraordinary precipitation (Merz et al. 2014, Schröter et al. 2015; Fig. 1, bottom right panel). At the onset of the June 2013 flood, the hydraulic load of large parts of the river 
Fig. 1. Hydro-meteorological characteristics of the August 2002 (left) and the June 2013 flood (right). Top panel: Initial wetness in terms of the antecedent precipitation index (API) and hydraulic load as the ratio of the streamflow at the event start (Qi) and the mean annual flood discharge (MHQ); bottom panel: event precipitation in terms of the maximum precipitation total within 3 days (Pmax 3-days) and the return period of peak discharges (Tn-Qp).
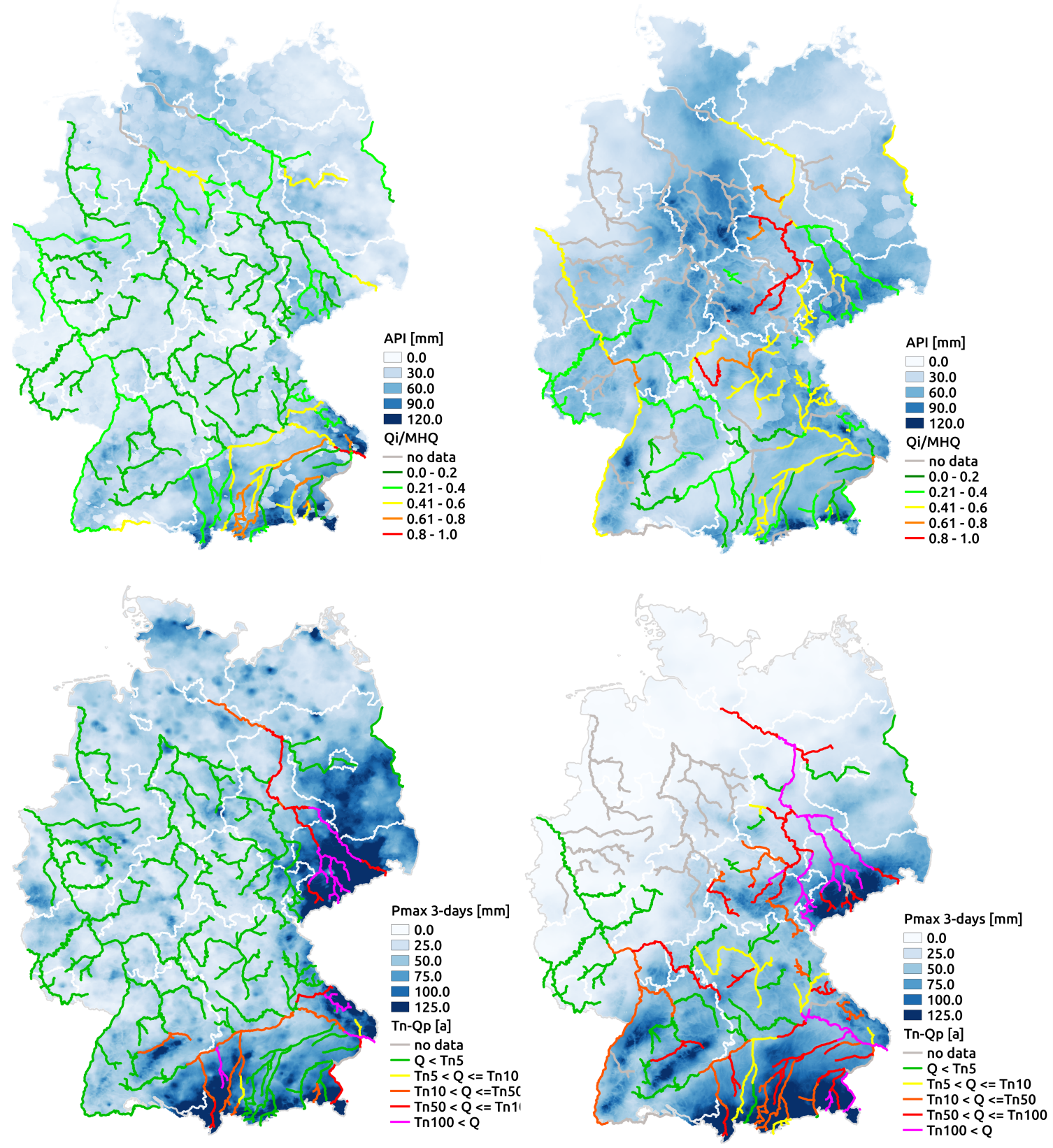

network in Germany was already increased and thus the conveyance capacity of river sections had already been strained (see Fig. 1, upper right panel, for a quantification of the initial hydraulic load in terms of the ratio of mean daily discharge at event start and the mean of annual maximum discharges; Schröter et al. 2015). The pattern of increased initial hydraulic load reflects the spatial distribution of high initial catchment wetness (Fig. 1, upper right panel) and applies mostly to the central and southeastern part of Germany. In comparison, for the August 2002 flood the initial hydraulic load of the river network was clearly lower except for some alpine tributaries of the Danube (Fig. 1, top left panel).

In August 2002, flooding occurred particularly along the river Elbe in the city of Dresden and downstream to the confluence of the river Mulde, along the Elbe tributaries in the Ore Mountains 
as well as the Regen River, a left-bank tributary of the Danube (Ulbrich et al. 2003, IKSE 2004). The flood in June 2013 was characterized by the slow development of an elongated flood wave carrying huge volumes of water with unusual simultaneous discharge contributions from the Elbe, Mulde, and Saale catchments (Conradt et al. 2013). Large-scale flooding affected almost all main river basins in Germany (Merz et al. 2014, Schröter et al. 2015). Severe flooding occurred along the rivers Danube, Elbe, and its tributaries Saale and Mulde. In Passau, the highest water level since 1501 was observed, because of the superposition of the flood waves from the rivers Inn and Danube (Blöschl et al. 2013, BfG 2014). Because of the large spatial extent of flood peaks with high magnitudes (Fig. 1, bottom right panel), the June 2013 flood was from a hydrological perspective the most severe flood in Germany at least for the last six decades (Schröter et al. 2015).

\section{Socioeconomic impacts}

With a total amount of $€ 11.6$ billion direct losses (reference year 2005; Thieken et al. 2006), the flood event of August 2002 has been the most expensive natural hazard event in Germany up to now. Eight of the 16 states reported losses. In addition, federal infrastructure was heavily affected; this involved federal assets like railways, motorways, navigable waterways, and administrative buildings. Saxony was by far the worst hit federal state - $75 \%$ of the overall losses originated here, followed by Saxony-Anhalt $(10 \%)$ and the Federal Government $(8 \%)$.

In 2013, 12 federal states announced losses and in parts of 8 a state of emergency was declared (BMI 2013). Even though the loss estimation of the June 2013 flood is still preliminary, the total direct losses will possibly not reach the sum of $€ 8$ billion that was reported to the European Solidarity Fund in July 2013 (Thieken et al. 2016). By July 2015, the overall losses were estimated to around $€ 6$ billion (Thieken et al. 2016). Again Saxony was the worst affected state with approximately $37 \%$ of the overall losses, followed by Saxony-Anhalt (28\%), Bavaria (21\%), Thuringia $(7 \%)$, and the Federal Government (2\%; data sources: DKKV 2015, Federal Parliament 2015).

From the overall losses, the insurance industry paid $€ 1.8$ billion in 2002 and $€ 1.65$ billion in 2013 (GDV 2015) even though the flood insurance penetration rose from 19\% in 2002 to $34 \%$ in 2013 (GDV 2014). Hence, not only overall losses dropped, but also the insured losses of the June 2013 flood were lower than in 2002.

\section{FLOOD RISK MANAGEMENT CHANGES IN GERMANY SINCE 2002}

The flood risk management in Germany was reviewed for three domains of flood risk management:

- retention of flood water and protection measures (flood control) to avoid inundation of (urban) areas,

- loss prevention by adapted use of flood-prone areas (including flood-adapted design and use of buildings and property-level mitigation measures), and

- preparedness for response and recovery (e.g., by risk transfer mechanisms).

Each section starts with the situation in 2002 according to DKKV (2003), highlights developments since 2002 as well as the performance during the 2013 flood event, and ends with some recommendations for the upcoming years.

\section{Flood control}

\section{Decentralized flood control measures}

"Every cubic meter of water that is retained through reclamation of floodplains, renaturation of surface water bodies, unsealing of land, seepage and site-appropriate agriculture and forestry, as well as through the preservation and promotion of small landscape structures for water retention, is a benefit for the ecosystem and relieves us in the case of flooding" (LAWA 1995:20; our translation). However, the effectiveness of measures for enhancing natural water retention, often referred to as decentralized flood control measures, to reduce extreme flood situations as of 2002 has often been overestimated. Hence, DKKV (2003) recommended developing benchmarks for the effectiveness of such measures with regard to different catchment sizes and flood intensities.

By 2013, studies on the assessment of the effectiveness of decentralized measures were published by the German Association for Water, Wastewater and Waste (DWA 2006), which highlight that such measures can be very effective in small catchments in the case of frequent floods and can moreover have positive effects for the surface water body ecologies, erosion control, and the restoration of the natural water balance. During the flood of 2013 it was further observed, e.g., in Dresden, that restored surface water bodies of the secondary category did not incur any flood damage. The flood event however revealed again that the discharge capacity especially at bridges and culverts must be always maintained to prevent backwater effects and hence minimize damage in the case of extreme events.

In addition, flood origination areas, i.e., areas with a high incidence of rainfall and quick runoff generation, have been mapped in Saxony. Statutory rules that aim to prevent surface sealing in these areas are part of the Saxon Water Act (SächsWG $\S 76$ as of 2015).

In general, decentralized flood control measures were not discussed after the 2013 event as intensively as in 2002. Instead, large-scale retention measures such as flood polders gained importance in the national flood protection program. With regard to European water policies, measures to improve natural water retention are an important field of action with potentially conflicting priorities between the European Water Framework Directive (2000/60/EC, EC 2000) and the European Floods Directive (2007/60/EC, EC 2007). The effects of measures on surface water bodies and in the catchment areas must therefore be identified for both directives with the goal to achieve or strengthen synergies. Furthermore, federal states should check whether it would be possible to implement the approach taken by Saxony to preserve infiltration capacities of areas in which surface runoff is quickly generated.

Flood control by polders and restoration of floodplains

Especially in the case of extreme floods, controlled retention basins (polders) are indispensable to cap flood peaks, as the activation of the Havel polder in Brandenburg demonstrated during the flood in August 2002 (Förster et al. 2005). Therefore, increased efforts to designate retention areas that can be flooded in a controlled and hence effective manner were requested in the 
aftermath of the 2002 flood (e.g., DKKV 2003). In addition, it was recognized that floodplains had been reduced to one third of their original extent in Germany and to 10 to $20 \%$ along large rivers and should thus be reactivated; where possible, embankments should be relocated to create more retention areas along the rivers (BfN 2009).

Also in 2013, controlled flood retention basins and dams have contributed to a marked capping of flood peaks in all affected river catchments (BfG 2014). However, retention capacities are still limited. Dike relocations and new polder areas have only been created occasionally. For example, the reactivation of 420 ha floodplain at Lenzen on the river Elbe is currently the biggest realized project in Germany and reduced flood water levels in 2013 (Promny et al. 2014). To further strengthen this flood management strategy, the Federal Environment Ministry set up a National Flood Protection Program together with the LAWA to identify potential areas for reactivation of floodplains, dike relocations, and new polder areas that are of national relevance. All projects shown in Figure 2 were assessed with several criteria, e.g., potential risk reduction, synergies with the water framework directive, costs etc. The program was agreed in October 2014, although the financing mechanism between the federal government and the federal states required further negotiations (DKKV 2015). Finally, it was agreed that the removal of weak points of flood protection schemes should be solely financed by the federal state in charge. Still, the implementation of the projects will take several years to decades.

Fig. 2. Projects of the National Flood Protection Program as of July 2014.

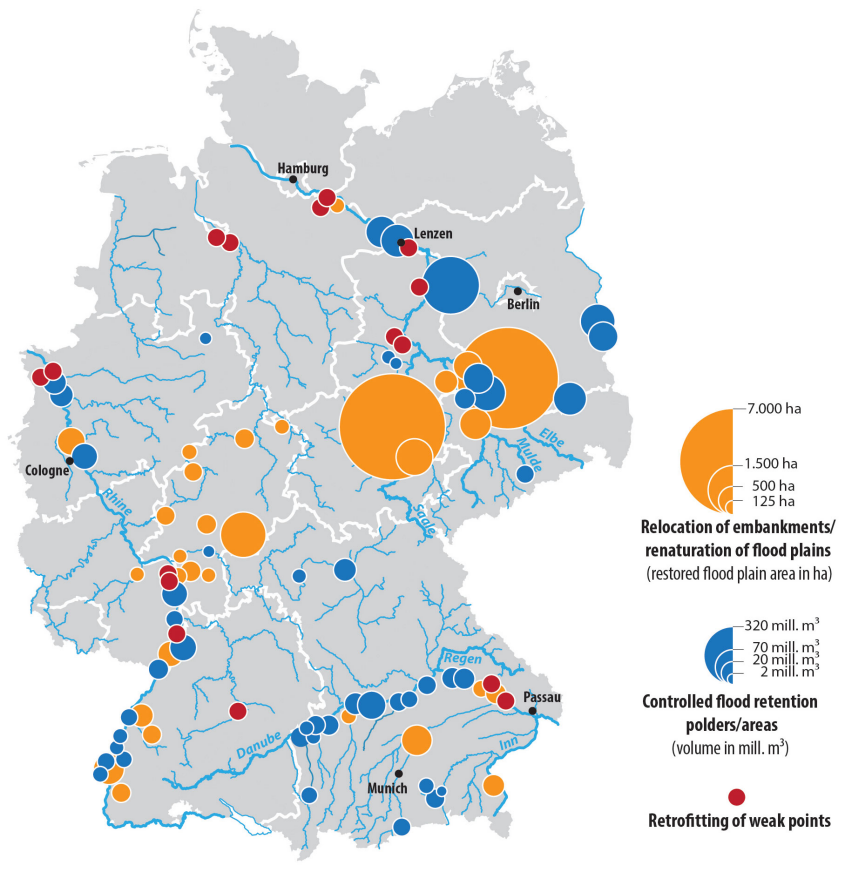

Flood defense by embankments

To protect areas from being inundated, in particular urban areas with high damage potential but also arable land, technical measures such as embankments have a long tradition (Bubeck et al. 2015) and have thus been in place along many rivers. However, technical measures provide safety only if they are well maintained and design levels are not surpassed. In 2002, however, overtopping and breaches of embankments were an important flood pathway. In total, 131 dikes failed in Saxony: 16 along the river Elbe and 115 in the Mulde catchment (DKKV 2003). DKKV (2003) verified that dams were in good condition before the 2002 flood, but embankments, especially along the Elbe and Mulde rivers, showed deficiencies. This was predominantly ascribed to unclear and disjointed responsibilities between the federal, the state, and the municipal level as well as to the high costs of maintenance. To prevent malfunctions, flood defense systems should thus be continuously monitored and maintained. Aside from having the issue of responsibility clarified, DKKV (2003) advised discussing societal-accepted safety levels. Moreover, the residual risk behind protective structures should be quantified and communicated.

With the introduction of the German industrial standard DIN 19700 in July 2004, the assessment of the risks of dam failures was brought up to date: spillways have to be designed for a 1000year flood discharge and the safety of the construction has to be proven for a 10,000-year flood discharge. Furthermore, extensive renewal and upgrading of embankments have been undertaken since 2002 so that considerably fewer breaches occurred in 2013. The systems strengthened since 2002 were able to withstand the hydraulic load in 2013 (LAWA 2014): only five breaches occurred in the Saxon part of the river Elbe and 24 failures along the river Mulde. Still, particularly three breaches, namely near Deggendorf at the Danube River, near Groß Rosenburg at the Saale River and near Fischbeck at the Elbe River had dramatic dimensions (Merz et al. 2014). These breaches demonstrated that leaking oil tanks can cause considerable material and environmental damage, which could be easily avoided by appropriate and comparatively inexpensive precautionary measures such as securing of oil tanks at household level (see Kreibich et al. 2011b). Altogether, the flood in June 2013 confirmed again that technical measures effectively protect (urban) areas up to the design event.

The levee breaches during the 2013 flood also suggest that the communication of the protection level of structures still has to be improved and that residents behind embankments have to develop precautionary and preparatory strategies. However, many more hazard maps, also showing potential flooding behind embankments, were accessible in 2013 because the effects of extreme events beyond the 100-year flood, which often serves as design event of a defense system, have to be investigated for the hazard maps according to the European Floods Directive. As a result, the level of private precaution behind embankments was already better in 2013 than in 2002 (DKKV 2015). This indicates that residents already acknowledge that embankments do not provide $100 \%$ protection. Still, potential failure scenarios must be presented more transparently and consistently, and a greater nuance of management strategies must be put up for discussion. For example, encircling and bulkhead dikes, as well as secondary lines of defense are being planned in Bavaria. Moreover, the floodsafe storage of heating oil tanks should be better monitored by the authorities in charge. The securing of oil tanks or a transition from oil to other forms of energy such as natural gas is worth encouraging in areas that will be inundated if flood defenses fail. 
Controversies on flood control measures

DKKV (2003) stressed that neither retention measures nor protection measures are a universal remedy, but should be incorporated into integrated, locally adapted concepts. The fact that flood protection schemes were strengthened after 2002 and less dike breaches occurred partially triggered a discussion whether activities in upstream areas aggravated the flood situation downstream. Furthermore, increasing flood water levels from 2002 in 2013 in certain reaches of the River Elbe hint to the problem that considerable aggradation had taken place in the dikes' forelands, which reduced the flood protection level. In some areas there has already been a reaction: for example, through the River Danube Foreland Management the flood water levels of the river Danube could be lowered. In other areas, solutions that coincide with nature conservation are being sought.

The public debate related to the flood in June 2013 also revealed that the planning and implementation of flood defense schemes form grounds for many disputes between authorities and the general public (Otto et al. 2016). On the one hand, protective measures are requested by parts of the affected population and enjoy strong acceptance in satisfying desires for safety. On the other hand they are rejected because of the side effects they have on the landscape and on nature, or because of particular usage interests (Otto et al. 2016). Mobile systems often serve as a compromise solution for the protection of urban areas, but in the case of an event these require deployment forces that are then no longer available for other tasks. To avoid disputes, the concerns and experiences of flood-prone residents and companies should be heard and entered into planning processes. Hence, early involvement, before the formal public hearings of the planning approval, is recommended (see Otto et al. 2016).

A more positive and creative attitude to the German multilevel governance system would be desirable. The subsidiary principle is advantageous for addressing regional specifics, but has its limits when the interests of others are affected. Transboundary issues must therefore be identified systematically to agree upon common strategic goals and find solutions. The drafts of the flood risk management plans as of 2014 reveal, however, that transnational coordination and prioritization measures, e.g., through costbenefit or multicriteria analyses, are seldom considered (DKKV 2015). Downstream effects of measures and transboundary issues are rarely addressed, but must not be neglected from a catchmentwide perspective. It is advisable that flood risk management plans include arrangements on how to exchange plans, knowledge, and information within the whole catchment, how to assess measures, and how to compensate for adverse effects of measures. In Germany, it would be worth considering a moderating role of the federal government.

The modeling study by Kienzler et al. (2015b) along the river Mulde suggests that a scenario with improved property-level mitigation and preparedness should be investigated and discussed as a reference management scenario. In areas that have not received flood protection because of regional prioritization procedures, alternatives must be developed, e.g., in the form of a systematic advancement of property-level mitigation and preparedness (Kreibich et al. 2015). Such alternatives should be communicated and financially supported by the government.

\section{Adapted use of flood-prone areas}

Reducing damage potential by flood-adapted land-use planning Decisive to reduce flood damage is the prevention of urban development and infrastructure in flood-prone areas. The 2002 flood revealed that spatial planning as an effective tool for loss prevention played a negligible role (Petrow et al. 2006). Hence, DKKV (2003) recommended that the legal rules for governing development in flood-prone areas must be formulated clearly and unambiguously. If not only a stagnation in damage potential, but also a real reduction is aimed at, financial means and incentives for reconstruction at another location (retreat or relocation) have to be discussed as well (DKKV 2003).

In Germany, flood-adapted spatial planning has received a considerable boost through the European Floods Directive (2007/60/EC) as well as through changes in the Federal Water Act in 2005 and 2009. By the end of 2013, flood hazard and risk maps were available in all German states and publicly accessible on the internet. However, maps are not necessarily tailored to the information needs and skills of the residents at risk (Meyer et al. 2012). Even so, there are still exceptions when it comes to the designation of new building areas and the densification of existing built-up areas, even in declared statutory flood plains. In addition, there are no restrictions for areas behind flood defenses. Only in Saxony has a grading system with regard to building conditions for flood-safe planning, construction, and rehabilitation been introduced after the 2013 flood (DKKV 2015).

Retreat with reconstruction of damaged buildings at another location has only been performed in isolated cases since 2002, e.g., in Röderau-Süd, near Dresden (Müller 2010), which among other things could be ascribed to the high costs, which will as a rule only be taken on partly by insurances or public authorities (DKKV 2015). In future, the role of relocation in flood risk management should be clarified. Legal provisions and financial concepts should subsequently be updated.

In urban planning, provision must also be made to inhibit further development and densification in statutory flood plains and existing flood-prone built-up areas. This must be safeguarded legally, so that exemption clauses can be kept to a minimum. In flood-prone areas, an entry of the flood hazard level into the land register is advisable so that adapted planning and construction is enforced at the outset.

\section{Strengthening of responsibility and contributions of property} owners

Before the 2002 flood, contributions of property owners to flood risk reduction, which includes preparedness for response, propertylevel mitigation measures, and flood insurance, had been inadequately developed. It was not sufficiently clear to people whether they live in a flood-prone area, how to protect themselves, and whether precautionary measures pay off (Kreibich et al. 2005). Helpful local information material was lacking. There were no tax incentives, nor were property-level mitigation measures rewarded by insurance companies (Thieken et al. 2006).

In 2005, the obligation to implement property-level mitigation measures was introduced in the Federal Water Act (WHG $\S 5$ as of 2009); however, the implementation thereof remains unclear. Staterun promotional programs are lacking, though insurance companies reward building precautionary measures more strongly 
today than in 2002 (DKKV 2015). In general, contributions of property owners were clearly more pronounced in 2013 than in 2002 (Fig. 3). In many communities, municipality-specific information material has been made publicly available. However, a stronger need for information still exists, especially in areas that are rarely affected by floods or that are located behind flood defense systems.

Fig. 3. Property-level mitigation measures performed by floodaffected residents before and after the flood in 2002 or 2013 and measures planned for the next six months. Note that some measures (marked in the figure with 1) can only be implemented by homeowners; hence tenants were not asked about their implementation.

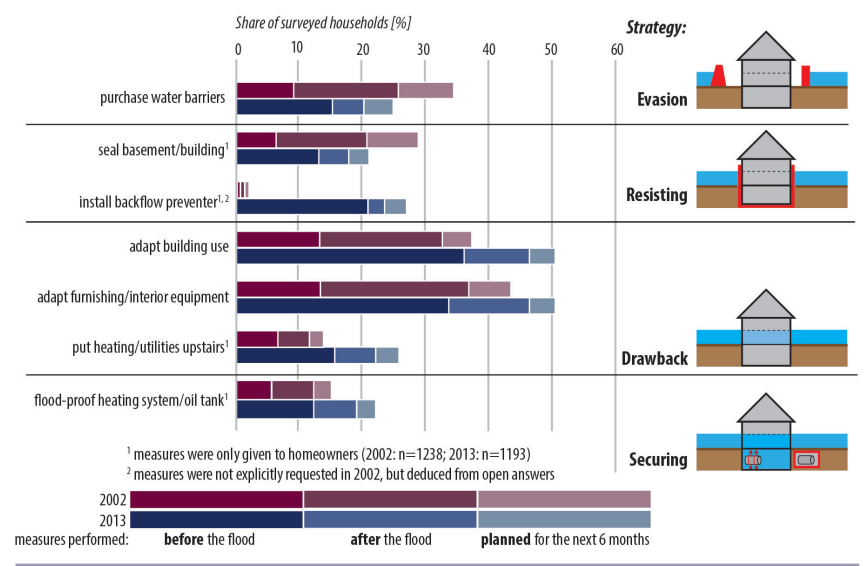

Because flood defense systems and disaster response can fail, precautionary self-provision must be further stimulated and honored, especially in the commercial sector and in areas that are not (well) protected (Kreibich et al. 2011a). For this purpose, the establishment of a funding and support program of the German Credit Institute for Reconstruction (KfW) should be considered. To systematically improve property-level flood risk reduction, the recently developed "flood passport" (Hochwasserpass) that supports a systematic object-specific risk assessment and reduction can be a helpful tool and should be better appreciated as a suitable adaptation measure to flood risk by banks and insurance companies in negotiations about mortgage or flood insurance coverage. This passport should also be tailored to the requirements of businesses. Moreover, advice on flood-adapted building design in flood-prone areas must be provided more systematically; building constraints or recommendations should be considered.

\section{Flood risk awareness}

Precautionary actions require risk awareness and consequently risk communication. After the 2002 flood, a lack of continuity in risk communication between flood events was observed. To counteract this deficit, a wide information campaign was called for, which should include the setup of flood marks, compilation and dissemination of hazard maps, creative educating ideas, as well as the communication of precautionary and coping strategies (DKKV 2003).

In general, all demanded activities of the information campaigns were implemented comprehensively over the years. An essential step in consolidating risk communication was made with the publicly available hazard and risk maps owing to the European Floods Directive (a German-wide overview of all official flood hazard and risk maps is provided by the German Federal Institute of Hydrology (BfG) http://geoportal.bafg.de/mapapps/resources/ apps/HWRMRL-DE/index.html?lang=de) and in the multihazard web portal "Kompass Naturgefahren" launched by the German Association of Insurers (GDV) for pilot regions. These maps are, however, often not sufficiently tailored to the needs and knowledge of the general public. Moreover, the provided hazard and risk information is often inadequately linked to precautionary measures and coping options.

To further improve flood risk information, the setup of a joint and nationwide natural hazard portal and related information campaigns of the federal government, the federal states, and the insurance industry was recommended by the German Conference of Environment Ministers in October 2014. Because information needs, coping capabilities, and adaptation capacities vary within the general public, certain subgroups, e.g., homeowners, tenants, or people with special needs, should be identified and addressed by tailored information and media. Finally, information on flood hazards, precautionary measures and coping possibilities should be linked more effectively.

\section{Preparedness for response and recovery}

\section{Flood warning}

In contrast to many other natural hazards, floods can be forecasted comparatively well, with the exception of flash floods, and up to several hours to days in advance. Thus the time up until the event fully evolves can be used for damage reduction by emergency measures such as the evacuation of places and buildings or the management of retention areas, e.g., the release of water from dams. In Germany, the German Weather Service (DWD) is responsible for providing warnings on extreme weather situations, while the federal states are responsible for flood forecasting, warning, and emergency response.

In 2002, the compilation and forecasts of the impending (flood) situations were often undifferentiated and released without an assessment of the dangers, so that the affected parties were unable to deduce appropriate and damage-reducing emergency actions (DKKV 2003). Integrated early warning systems from monitoring through to the reaction of the affected parties were insufficiently developed and hardly evaluated. Besides better risk communication, maintenance and upgrading of models and systems to the latest technologies as well as more efforts to provide up-to-date and reliable input data for the forecast models were hence recommended (DKKV 2003, Thieken et al. 2005a).

By June 2013, clear progresses in the technical systems and the organization of warnings were discernible at all levels. The DWD has improved all numerical forecast models, introduced uncertainty assessment by ensemble simulations, and disseminated warnings by various media including web-based services. The DWD has teamed up with emergency response units in the districts and (regional) flood forecasting centers that use precipitation forecasts as one main input for their rainfall-runoffmodels (DKKV 2015). With regard to flood warnings, farreaching cross-departmental and transnational collaboration across the federal states has been achieved. In some federal states, 
e.g., in Lower Saxony, Saxony, and Thuringia, flood forecasting and warning was reorganized after 2002; dissemination and communication pathways were clearly defined and feedback loops were established to avoid interruptions of the alerting process (DKKV 2015). In addition, an internet portal (http:// www.hochwasserzentralen.de) was established to allow a countryand basin-wide assessment of the flood situation, which was impossible in 2002. However, this crisis communication is to some extent not consistent with risk communication. For instance, hazard maps are not well linked to warning stages, and the term "extreme flood" is interpreted differently.

In 2013, precipitation and runoff forecasts were in general precise and were issued well in advance (e.g., DWD 2013, DKKV 2015). In places there were, however, inaccuracies in the rainfall forecasts that propagated in the runoff forecasts. Occasionally, the all-clear signal was given too soon or an overload of the IT-systems occurred, so that the exchange of data and its onward transmission was compromised. Also the timely and reliable identification of levee breaches and their effects on the flood situation downstream as well as on the inundation of the hinterland was difficult, e.g., in Bavaria and Saxony-Anhalt (DKKV 2015).

Because the quality of flood forecasts largely depends on the quality of rainfall forecasts, the latter should be further improved. In addition, rainfall-runoff-models should be expanded, especially with regard to a common appraisal of uncertainties. In situations where levee breaches might occur, new procedures for rapid hydraulic modeling or appraisal of the inundation would be particularly valuable; approaches to identify potential breach locations and their sizes should be further investigated. Finally, continuity, redundancy, and capacity of the technical systems and staff must be guaranteed. In this process, the training of staff deserves special attention.

\section{Emergency response}

Because integrated early warning systems were insufficiently developed by 2002, warnings hardly contained any information on what affected parties should do to protect themselves and to mitigate flood damage (Thieken et al. 2007). Therefore, DKKV (2003) recommended significantly improving the activity orientation of warnings. Residents, businesses as well as authorities were hardly prepared for the 2002 event (Kreibich and Thieken 2009). For instance, only 10\% of affected companies had emergency plans available, and only $4 \%$ had undertaken flood emergency exercises before August 2002 (Kreibich et al. 2007).

Solidarity with affected parties was high during the event; basically all helped each other. However, integration of volunteers in emergency management was challenging in terms of logistics and liability issues. To strengthen individual, commercial, and public emergency management capacities, strategic thinking and practical exercises need to be undertaken early and continuously (DKKV 2003).

In contrast to 2002, residents, businesses, and authorities were significantly better prepared in 2013, probably due to intense flood experience as well as improved risk and emergency communication (Kreibich et al. 2011a). For instance, in 2002 only $14 \%$ of private households clearly knew how to protect themselves and their assets, in 2013 this fraction was $46 \%$ (Fig. 4).
Fig. 4. Answers of flood-affected residents to the question whether they knew how to protect themselves and their assets from the flood.

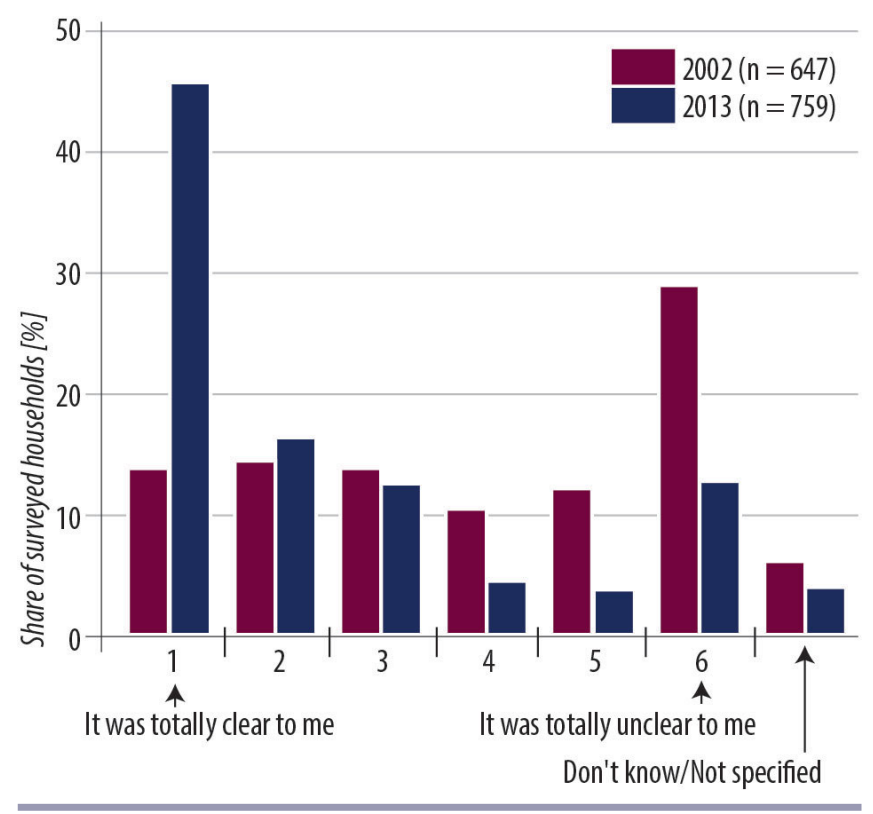

During the 2013 flood, emergency management and disaster control as well as affected people and companies reacted to the warnings significantly more effectively than in 2002 (DKKV 2015). Collaboration within and among different disaster response organizations has clearly gained in effectiveness because of the coordination by the joint reporting and situation center (GMLZ) and transnational exercises, e.g., the biennial transnational crisis management exercise LÜKEX, but it is still complicated by state-specific provisions (DKKV 2015). Again, many volunteers wanted to support the emergency management during the flood in 2013. In contrast to 2002, they organized themselves via social media in many places and partly acted parallel to or independently from established disaster response organizations. The phenomenon of the "independent helpers" reached a new dimension in self-organization and created a momentum of support.

Comprehensive communication along the warning chain has been largely achieved, but should be evaluated, exercised, and further improved continually. An honest communication that presents and prepares for possible protection failures would be beneficial for all stakeholders. Protection failures, such as levee breaches, should be integrated into crisis management exercises, e.g., LÜKEX. Interorganizational exercises strongly support a high performance capacity of emergency response. To integrate "independent helpers" into disaster response more effectively, new approaches must be developed. Platforms based on the example of Team Austria (http://apps.teamoesterreich.at) are highly promising.

\section{Risk transfer and recovery}

If flood damage cannot be avoided, risk transfer mechanism help to distribute the financial burden within the society based on the 
principle of mutual solidarity. In Germany, flood insurance is in principle available for private households and commercial or industrial enterprises. It is usually offered as a selectable add-on to property insurance or if it is already included, it can be opted out. Furthermore, there are insurance products that cover business interruption losses caused by flooding. Insurance penetration has been inching up over the last years, i.e., flood insurance of buildings rose from $19 \%$ in 2002 to $34 \%$ in 2013 (GDV 2014), reached 38\% in 2015 (GDV 2015), but is still comparatively low. Therefore, governmental aid is occasionally provided. After the flood in 2002, €7.1 billion was made available from the Federal Government for reconstruction of affected infrastructure as well as for restoring flood-affected private households and companies. But the allocation of the funds was not linked to precautionary measures (DKKV 2003). Therefore, the opportunity to correct past organizational, building and planning errors during the reconstruction was largely underexploited after the 2002 event.

Also during the 2013 event, great solidarity was discernible. Once again $€ 8$ billion was made available for reconstruction at short notice, not only to restore damaged households and companies, but also to repair damaged infrastructure. In 2013, resource allocation to affected residents and companies appears to have been handled more restrictively than after the 2002 flood (DKKV 2015). Regrettably, the opportunity to combine reconstruction with risk reduction was missed once again. On the contrary, generous state assistance creates few incentives for future selfprovision, e.g., by contracting flood insurance, even if the past shows that state reconstruction aid is usually not provided for small events. Analyses by Thieken et al. (2006) and DKKV (2015) reveal that losses of insured households are compensated more reliably and faster than losses of uninsured.

Ad-hoc decisions on reconstruction aid should be replaced by a structured risk transfer system that must take into account the current form of insurance against damage caused by natural hazards. For this purpose, a clear legislation for reconstruction assistance, e.g., in the form of a federal loss compensation guideline is necessary. Overall, the link between reconstruction and risk reduction should be strengthened on all levels (federal government, federal states, municipalities, insurance companies, companies, and private households).

\section{TOWARD A MORE INTEGRATED FLOOD RISK MANAGEMENT}

To be effective and efficient the different flood risk reduction measures addressed above have to be combined and well balanced across sectoral, regional, or national borders. The repeated flood events over the last 20 years have demonstrated that this is already challenging in multilevel governance systems. Furthermore, the debate on climate change and land-use development implies that flood risks can further change in the future. Successful flood risk management is hence not a singular action, but requires continual evaluation and adaptation to changing boundary conditions as is already foreseen by the regular updates of the tasks in the European Floods Directive (EC 2007). Therefore, we recommend reinterpreting the flood risk management cycle in order to accomplish the following (Fig. 5):

1. to recognize events systematically as a performance test and opportunity to remove weak points,
2. to adapt risk reduction strategies to new boundary conditions, and

3. to monitor flood risk and develop well-balanced risk reduction and coping strategies.

Fig. 5. Enhanced cycle of flood risk management.

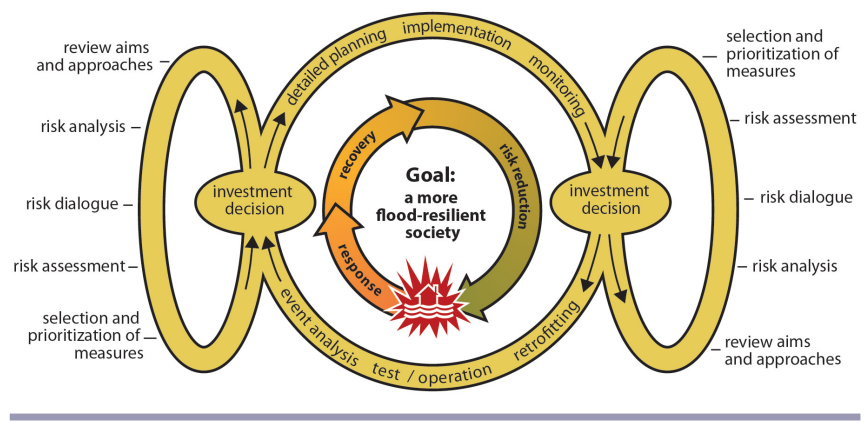

A proposal for an enhanced flood risk management cycle

Flood events serve as an opportunity to investigate risk reduction measures, their effectiveness, and their interaction in a river basin to identify and remove weak points. Improvements in flood risk management since 2002 show that such learning processes take effect on many levels. Progresses in flood warning, property-level mitigation (self-provision), and disaster response as well as the improved efficiency of flood defenses serve as good examples for this. To fully exploit their learning potential, loss events should be well documented and analyzed. However, a comparison of documentations of the 2013 flood published by different water authorities quickly reveals that the scope and content of such reports are very diverse; some do not even contain conclusions or recommendations (DKKV 2015). Thus the development of standardized interdisciplinary event documentations and data archives is urgently recommended.

Any lessons-learned evaluation of damaging events should, however, go beyond an analysis and removal of weak points. Damaging events call for a thorough reflection of flood risk management strategies. Therefore, the traditional cycle of risk management was augmented by a second loop in Figure 5. At the junction, scrutiny of existing targets in risk management (e.g., safety levels), decision criteria and assessment methods, responsibilities, as well as the mixture and prioritization of measures is essential in order to be in a position to undertake strategic changes. As a rule, the timeliness and completeness of hazard and risk scenarios used for planning must be reflected, e. g., the most recent event has to be incorporated in (frequency) analyses and scenarios. Furthermore, event and risk analyses also ought to take account of the impact of climate change and societal changes, e.g., land-use changes, demographic changes, changes in flood risk management, as well as behavior and capacities of people at risk, that could impact on the extent of damage. Full costs should be considered (Kreibich et al. 2014). Because these appraisals are uncertain, it has also to be discussed how flexible and robust flood defenses and precautionary measures are or how they could be designed and equipped to be more flexible. Instead of ever-increasing design values, the upgradability of flood 
defenses, the development of fail-safe strategies, and the rigorous consideration of residual risks are essential. Therefore, a participatory two-way risk dialogue must be established.

Although everyday politics tend to withstand strategic changes in favor of incremental changes, (extreme) loss events offer a window of opportunity for a strategic reorientation as is marked by the National Flood Protection Program (Fig. 2). However, high-impact events call for quick political responses. Therefore, it is recommended to adapt existing concepts and strategies in flood-free times as laid out in the European Floods Directive: the preliminary risk assessment, hazard maps and risk maps, and the management plans must be updated every six years (EC 2007). This statutory revision should be used to further develop catchment-wide integrated risk management strategies. For this, experiences, i.e., both successes and challenges, should be systematically assessed in planning and implementation, in order for processes and procedures to be scrutinized and revised where appropriate.

\section{CONCLUSIONS}

The review of flood risk management in Germany after the flood in June 2013 highlights considerable improvements since 2002 on many levels, in particular (1) an increased consideration of flood hazards in spatial planning and urban development, (2) comprehensive property-level mitigation and preparedness measures, (3) more effective flood warnings and improved coordination of disaster response, and (4) a more targeted maintenance of flood defense systems. In 2013, this led to more effective flood event management than in 2002 and to a reduction of damage: although the flood of 2013 is regarded in hydrological terms as the most severe flood event in the last decades, the total damage is by far lower than it was in 2002. Nevertheless, four important aspects remain unclear and need to be further investigated and clarified.

1. Balanced and coordinated strategies for reducing and coping with the impacts of flooding: technical flood protection always plays a big role in reducing the impacts of flooding. However, extreme events reveal its limitations. To remain capable of responding in cases where protective structures fail, other management approaches, such as retention, property-level measures, warning, and disaster response, have to be further improved. Furthermore, the effectiveness of protective structures has to be checked at regular intervals and secured through maintenance and repair, also in the forelands of embankments. To achieve a sustainable reduction of damage, preventive measures must be more consistently implemented, also in areas behind embankments. Replacement or securing of oil tanks represents an important contribution here, to minimize damage to property and the environment. Planning mistakes have to be corrected. With regard to this, among other things the role and feasibility of resettlements (retreat) has to be clarified.

2. Transboundary and cross-sectoral cooperation: because flooding does not stop at national borders and its impact is not confined to specific sectors, risk reduction and disaster response have to be coordinated among various stakeholders and administrative units. Where cooperation is necessary, the issues have to be systematically identified and clearly anchored in flood risk management plans. This particularly applies to methods for assessing risk and prioritizing measures within the river basins.

3. The role of the general public: on the one hand potentially affected persons are obliged to inform themselves and to implement mitigation measures at property levels; on the other hand they are often involved too late in planning processes, e.g., for flood protection. This inconsistency is to be resolved by a risk dialogue on equal footing, to enable local interests, experiences, and knowledge to be integrated into locally adapted risk management strategies. Furthermore, binding regulations are to be established for incorporating the results of such a dialogue in the planning process. To enhance coping capacities, concepts for involving volunteers during events have to be developed.

4. Transparent risk transfer system: the current coexistence of natural hazards insurance and ad-hoc decisions on governmental reconstruction aid provides little incentive for self-provision in Germany, even if governmental aid is not granted for smaller events and insured households are more reliably and quickly compensated than uninsured. Therefore, ad-hoc decisions on reconstruction aid are to be replaced by a transparent, nationally consistent risk transfer system, which takes into consideration the current form of insurance and enables the improvement of the resilience level of a damaged structure during reconstruction to build back better.

In summary, the LAWA guidelines of 1995 marked a new way of thinking toward integrated flood risk management in Germany. However, these have subsequently not been rigorously translated into action. The August 2002 flood induced legislative changes, for example, the European Floods Directive and amendments of the Federal Water Act, by which flood risk management, and particularly loss prevention, were strengthened. Nevertheless, actual enforcement is still strongly characterized by planning and implementing structural flood defenses. After the flood in June 2013 , bigger strategic changes are discernible. The systematic search and creation of retention space seen in the National Flood Protection Program is one example of a further rejection of a purely protective concept, even if this is not always reflected in the terminology. As a result of the 2013 event and with the current legislation, there is a chance that a more integrated flood risk management will become permanently implemented.

Responses to this article can be read online at: http://www.ecologyandsociety.org/issues/responses. $\mathrm{php} / 8547$

\section{Acknowledgments:}

The research presented in this paper was conducted in the framework of the project "Hochwasser 2013" funded by the German Ministry of Education and Research (BMBF; funding contracts: 13N13016, 13N13017). Support and cooperation by all ministries and organizations involved as well as by the Forensic Disaster Analysis (FDA) Task Force of the Center for Disaster Management and 
Risk Reduction Technology (CEDIM) in Potsdam and Karlsruhe is gratefully acknowledged. Finally, we acknowledge the support of the Deutsche Forschungsgemeinschaft and the Open Access Publishing Fund of the University of Potsdam.

\section{LITERATURE CITED}

Bárdossy, A., and F. Filiz. 2005. Identification of flood producing atmospheric circulation patterns. Journal of Hydrology 313:48-57. http://dx.doi.org/10.1016/j.jhydrol.2005.02.006

BfG (German Federal Institute of Hydrology). 2014. Das Hochwasserextrem des Jahres 2013 in Deutschland: Dokumentation und Analyse. Report. BfG, Koblenz, Germany.

Blöschl, G., T. Nester, J. Komma, J. Parajka, and R.A.P. Perdigão. 2013. The June 2013 flood in the Upper Danube Basin, and comparisons with the 2002, 1954 and 1899 floods. Hydrology and Earth System Sciences 17:5197-5212. http://dx.doi.org/10.5194/ $\underline{\text { hess-17-5197-2013 }}$

Bubeck, P., H. Kreibich, E. C. Penning-Rowsell, W. J. W. Botzen, H. de Moel, and F. Klijn. 2015. Explaining differences in flood management approaches in Europe and in the USA - a comparative analysis. Journal of Flood Risk Management http:// dx.doi.org/10.1111/jfr3.12151

Bundesamt für Naturschutz (BfN). 2009. Flussauen in Deutschland - Erfassung und Bewertung des Auenzustandes. BfNSchriftenreihe "Naturschutz und Biologische Vielfalt," Bonn, Germany.

Bundesministerium des Innern (BMI). 2013. Bericht zur Flutkatastrophe 2013: Katastrophenhilfe, Entschädigung, Wiederaufbau. Kabinettsbericht vom 04.09.2013, BMI, Berlin, Germany. [online] URL: http://www.bmi.bund.de/SharedDocs/Downloads/ DE/Broschueren/2013/kabinettbericht-fluthilfe.html

Conradt, T., M. Roers, K. Schröter, F. Elmer, P. Hoffmann, H. Koch, F. F. Hattermann, and F. Wechsung. 2013. Comparison of the extreme floods of 2002 and 2013 in the German part of the Elbe River basin and their runoff simulation by SWIM-live. Hydrol Wasserbewirtsch 57:241-245.

Deutsches Komitee Katastrophenvorsorge(DKKV), editors. 2003. Lessons learned - Hochwasservorsorge in Deutschland Lernen aus der Katastrophe 2002 im Elbegebiet. Schriftenreihe des DKKV 29, Bonn, Germany.

Deutsches Komitee Katastrophenvorsorge (DKKV), editors. 2015. Das Hochwasser im Juni 2013 - Bewährungsprobe für das Hochwasserrisikomanagement in Deutschland. Schriftenreihe des DKKV 53, Bonn, Germany.

Deutsche Vereinigung für Wasserwirtschaft, Abwasser und Abfall (DWA). 2006. Dezentrale Maßnahmen zur Hochwasserminderung. DWA, Hennef, Germany.

Deutscher Wetterdienst (DWD), editors. 2013. Das Hochwasser an Elbe und Donau im Juni 2013. Berichte des Deutschen Wetterdienstes 242, Offenbach, Germany.

Engel, H. 2004. The flood event 2002 in the Elbe River basin: causes of the flood, its course, statistical assessment and flood damages. Houille Blanche 6:33-36. http://dx.doi.org/10.1051/ $\underline{\text { lhb:200406003 }}$
European Commission (EC). 2000. Directive 2000/60/EC of the European Parliament and of the Council of 23 October 2000 establishing a framework for community action in the field of water policy (Water Framework Directive). EC, Brussels, Belgium.

European Commission (EC). 2007. Directive 2007/60/EC of the European Parliament and of the Council of 23 October 2007 on the assessment and management of flood risks (Floods Directive). EC, Brussels, Belgium.

Federal Parliament. 2015. Print matter 18/5641. Answer of the Federal Government to the small enquiry of the representatives B. Höhn, S.-Ch. Kindler, P. Meiwald, further representatives and the parliamentary party BÜNDNIS 90/DIE GRÜNEN. 18th legislative period, Berlin, Germany. [Translated from the German].

Förster, S., D. Kneis, M. Gocht, and A. Bronstert. 2005. Flood risk reduction by the use of retention areas at the Elbe River. International Journal of River Basin Management 3(1):21-29. http://dx.doi.org/10.1080/15715124.2005.9635242

Gesamtverband der Deutschen Versicherungswirtschaft (GDV). 2014. Online-Serviceteil zum Naturgefahrenreport 2014. GDV, Berlin, Germany. [online] URL: http://www.gdv.de/wp-content/ uploads/2014/10/Naturgefahrenreport-2014_Zahlen-Serviceteil_GDV. pdf

Gesamtverband der Deutschen Versicherungswirtschaft (GDV). 2015. Online-Serviceteil zum Naturgefahrenreport 2015. GDV, Berlin, Germany. [online] URL: http://www.gdv.de/wp-content/ uploads/2015/11/GDV-Naturgefahrenreport-2015-UnwetterbilanzVersicherer-OnlineServiceteil-n.pdf

Grams, C. M., H. Binder, S. Pfahl, N. Piaget, and H. Wernli. 2014. Atmospheric processes triggering the central European floods in June 2013. Natural Hazards and Earth System Sciences 14:1691-1702. http://dx.doi.org/10.5194/nhess-14-1691-2014

Hartmann, T., and J. Albrecht. 2014. From flood protection to flood risk management: condition-based and performance-based regulations in German water law. Journal of Environmental Law 26(2):243-268. http://dx.doi.org/10.1093/jel/equ015

Heintz, M. D., M. Hagemeier-Klose, and K. Wagner. 2012. Towards a risk governance culture in flood policy_-findings from the implementation of the "Floods Directive" in Germany. Water 4(1):135-156. http://dx.doi.org/10.3390/w4010135

Internationale Kommission zum Schutz der Elbe (IKSE). 2004. Dokumentation des Hochwassers vom August 2002 im Einzugsgebiet der Elbe. IKSE, Magdeburg, Germany.

Kienholz, H., B. Krummenacher, A. Kipfer, and S. Perret. 2004. Aspects of integral risk management in practice - considerations with respect to mountain hazards in Switzerland. Österreichische Wasser- und Abfallwirtschaft 56:43-50.

Kienzler, S., D. Falter, S. Jentsch, and A. H. Thieken. 2015b. Reduktion von Hochwasserschäden im Zusammenspiel von staatlicher und privater Vorsorge - eine Fallstudie an der Mulde. $K W$ - Korrespondenz Wasserwirtschaft 8(11):680-687.

Kienzler, S., I. Pech, H. Kreibich, M. Müller, and A. H. Thieken. 2015a. After the extreme flood in 2002: changes in preparedness, response and recovery of flood-affected residents in Germany 
between 2005 and 2011. Natural Hazards and Earth System Sciences 15:505-526. http://dx.doi.org/10.5194/nhess-15-505-2015

Kreibich, H., P. Bubeck, M. Van Vliet, and H. De Moel. 2015. A review of damage-reducing measures to manage fluvial flood risks in a changing climate. Mitigation and Adaptation Strategies for Global Change 20(6):967-989. http://dx.doi.org/10.1007/ s11027-014-9629-5

Kreibich, H., S. Christenberger, and R. Schwarze. $2011 b$. Economic motivation of households to undertake private precautionary measures against floods. Natural Hazards and Earth System Sciences 11:309-321. http://dx.doi.org/10.5194/ nhess-11-309-2011

Kreibich, H., M. Müller, A. H. Thieken, and B. Merz. 2007. Flood precaution of companies and their ability to cope with the flood in August 2002 in Saxony, Germany. Water Resources Research 43(3). http://dx.doi.org/10.1029/2005WR004691

Kreibich, H., I. Seifert, A. H. Thieken, E. Lindquist, K. Wagner, and B. Merz.2011a. Recent changes in flood preparedness of private households and businesses in Germany. Regional Environmental Change 11(1):59-71. http://dx.doi.org/10.1007/ $\underline{\text { s10113-010-0119-3 }}$

Kreibich, H., and A. H. Thieken. 2009. Coping with floods in the city of Dresden, Germany. Natural Hazards 51(3):423-436. http:// dx.doi.org/10.1007/s11069-007-9200-8

Kreibich, H., A. H. Thieken, T. Petrow, M. Müller, and B. Merz. 2005. Flood loss reduction of private households due to building precautionary measures - lessons learned from the Elbe flood in August 2002. Natural Hazards and Earth System Sciences 5:117-126. http://dx.doi.org/10.5194/nhess-5-117-2005

Kreibich, H., J. C. J. M. van den Bergh, L. M. Bouwer, P. Bubeck, P. Ciavola, C. Green, S. Hallegatte, I. Logar, V. Meyer, R. Schwarze, and A. H. Thieken. 2014. Costing natural hazards. Nature Climate Change 4:303-306. http://dx.doi.org/10.1038/ nclimate 2182

LAWA (Bund/Länder-Arbeitsgemeinschaft Wasser). 1995. Leitlinien für einen zukunftsweisenden Hochwasserschutz. Hochwasser - Ursachen und Konsequenzen. LAWA, Stuttgart, Germany. [online] URL: http://lawa.de/documents/Leitlinien_d59. pdf

LAWA (Bund/Länder-Arbeitsgemeinschaft Wasser). 2014. Zusammenfassende Analyse der Ergebnisse der vom Hochwasser 2013 betroffenen Flussgebietsgemeinschaften. LAWA, Stuttgart, Germany. [online] URL: http://www.lawa.de/documents/ BV TOP 34 Anlage Bericht 40b.pdf

Merz, B., F. Elmer, M. Kunz, B. Mühr, K. Schröter, and S. Uhlemann-Elmer. 2014. The extreme flood in June 2013 in Germany. Houille Blanche 1:5-10. http://dx.doi.org/10.1051/ $\underline{\mathrm{lhb} / 2014001}$

Meyer, V., C. Kuhlicke, J. Luther, S. Fuchs, S. Priest, W. Dorner, K. Serrhini, J. Pardoe, S. McCarthy, J. Seidel, G. Palka, H. Unnerstall, C. Viavattene, and S. Scheuer. 2012. Recommendations for the user-specific enhancement of flood maps. Natural Hazards and Earth System Sciences 12:1701-1716. http://dx.doi. org/10.5194/nhess-12-1701-2012
Müller, U. 2010. Hochwasserrisikomanagement: Theorie und Praxis. Vieweg+Teubner, Wiesbaden, Germany. http://dx.doi. org/10.1007/978-3-8348-9729-9

Otto, A., A. Hornberg, and A. H. Thieken. 2016. Local controversies of flood risk reduction measures in Germany. An explorative overview and recent insights. Journal of Flood Risk Management. http://dx.doi.org/10.1111/jfr3.12227

Petrow, T., A. H. Thieken, H. Kreibich, B. Merz, and C. H. Bahlburg. 2006. Improvements on flood alleviation in Germany: lessons learned from the Elbe flood in August 2002. Environmental Management 38:717-732. http://dx.doi.org/10.1007/s00267-005-6291-4

Petrow, T., J. Zimmer, and B. Merz. 2009. Changes in the flood hazard in Germany through changing frequency and persistence of circulation patterns. Natural Hazards and Earth System Sciences 9:1409-1423. http://dx.doi.org/10.5194/nhess-9-1409-2009

Promny, M., M. Hammer, and N. Busch. 2014. Untersuchung zur Wirkung der Deichrückverlegung Lenzen auf das Hochwasser vom Juni 2013 an der unteren Mittelelbe. $K W$ 7(6):344-349.

Schröter, K., M. Kunz, F. Elmer, B. Mühr, and B. Merz. 2015. What made the June 2013 flood in Germany an exceptional event? A hydro-meteorological evaluation, Hydrology and Earth System Sciences 19:309-327. http://dx.doi.org/10.5194/hess-19-309-2015

Thieken, A. H., T. Bessel, S. Kienzler, H. Kreibich, M. Müller, S. Pisi, and K. Schröter. 2016. The flood of June 2013 in Germany: how much do we know about its impacts? Natural Hazards and Earth System Sciences. http://dx.doi.org/10.5194/nhess-2015-324

Thieken, A. H., U. Grünewald, B. Merz, T. Petrow, S. Schümberg, H. Kreibich, W. Streitz, and M. Kaltofen. 2005a. Flood risk reduction in Germany after the Elbe 2002 flood: aspects of hazard mapping and early warning systems. Pages 145-156 in M. F. Buchroithner, editors. Proceedings of the International Symposium on Cartographic Cutting-Edge Technology for Natural Hazard Management. Kartographische Bausteine, Band 30, Dresden, Germany.

Thieken, A. H., H. Kreibich, M. Müller, and B. Merz. 2007. Coping with floods: preparedness, response and recovery of flood-affected residents in Germany in 2002. Hydrological Sciences Journal 52(5):1016-1037. http://dx.doi.org/10.1623/ hysj.52.5.1016

Thieken, A. H., M. Müller, H. Kreibich, and B. Merz. $2005 b$. Flood damage and influencing factors: new insights from the August 2002 flood in Germany. Water Resources Research 41(12). http://dx.doi.org/101029/2005WR004177

Thieken, A. H., T. Petrow, H. Kreibich, and B. Merz. 2006. Insurability and mitigation of flood losses in private households in Germany. Risk Analysis 26(2):383-395. http://dx.doi. org/10.1111/j.1539-6924.2006.00741.X

Ulbrich, U., T. Brücher, A. H. Fink, G. C. Leckebusch, A. Krüger, and J. G. Pinto. 2003. The central European floods of August 2002: Part 1 - Rainfall periods and flood development. Weather 58:371-377. http://dx.doi.org/10.1256/wea.61.03A 